\title{
SCIENTIFIC SUBSTANTIATION OF THE CREATION OF THE DOMESTIC HYGIENIC CLASSIFICATION OF CHILDREN'S CLOTHES
}

\author{
Platonova A.H., Yatskovska N.Ya., Antomonov M.Yu.
}

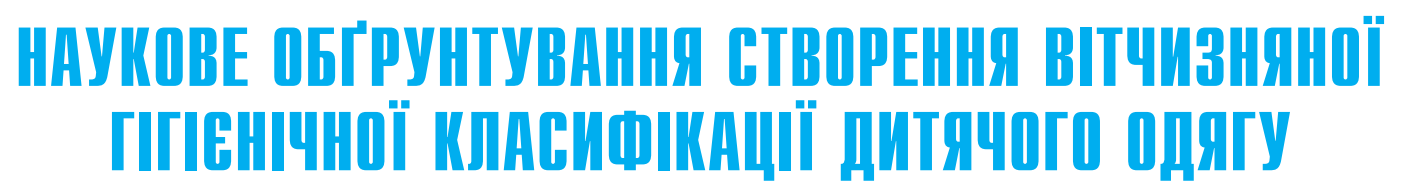

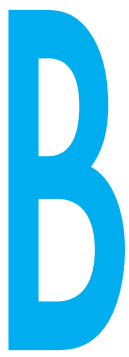

епоху глобалізації на міжнародному і національному рівнях увага громадськості, у тому числі наукової, прикута до питань збереження здоров'я населення, зокрема дитячого. Останнім часом ситуація зі здоров'ям дітей наблизилась до критичної. До особливостей негативних зрушень здоров'я дитячого населення у сучасних умовах

ПЛАТОНОВА А.Г. ЯЦКОВСЬКА Н.Я., АНТОМОНОВ М.Ю.

ДУ «ннститут громадського здоров'я ім. О.М. Марзєєва

НАМН України», м. Київ

Удк $613.95: 613.48$ належать стрімке збільшення кількості хронічних хвороб, зниження рівня та ступеня гармонійності фізичного розвитку, зростання психічних відхилень і порушень поведінки, порушень репродуктивної системи [1].

Нині численними науковими

Ключові слова: дитячий одяг, метод інтегральних оцінок, індекс безпеки, вітчизняна гігієнічна класифікація. них позицій навколишнє середовище - це сукупність природних та соціальних елементів, з якими людина нерозривно пов'язана, які впливають на неї протягом усього життя як середовище існування. Відомо, що під зовнішнім оточенням розуміють частину довкілля, що безпосередньо контактує з епітелієм шкіри слизовими оболонками та впливає на усі види рецепторів людини, що сприймають навколишній світ індивідуально [4].

Оточуюче дитину середовище дедалі стає все більш агресивним внаслідок забруднення, використання нових матеріалів, різноманітного побутового і учбового обладнання, здатного змінити якість середовища життєдіяльності дітей Тому одним 3 найактуальніших завдань профілактичної меди-
НАУЧНОЕ ОБОСНОВАНИЕ СОЗДАНИЯ ОТЕЧЕСТВЕННОЙ ГИГИЕНИЧЕСКОЙ КЛАССИФИКАЦИИ ДЕТСКОЙ ОДЕЖДЫ Платонова А. Г., Яцковская Н.Я., Антомонов М.Ю. ГУ «Институт общественного здоровья им. А.Н. Марзеева НАМН Украины», Г. Киев

Актуальность. Одним из ведущих факторов в охране здоровья населения, в том числе и детского, является обеспечение его безопасными предметами обихода. Предупреждение отрицательного влияния на здоровье человека неблагоприятных факторов, связанных с производством и появлением на рынке Украины потенци ально небезопасной продукции, требует пересмотра методических подходов и научного обоснования необходимости использования новых показателей для гигиенической оценки современных текстильных изделий.

Цель. Была установлена степень опасности отдельных видов одежды для здоровья детей и предложена отечественная гигиеническая классификация. Материалы и методы. Был использован метод интегральной оценки, дающий возможность определить индекс безопасности отдельных видов одежды.

Результаты. В соответствии с технологией построения интегральных оценок на первом этапе были определены информативные показатели безопасности отдельных видов одежды. К ним были отнесены площадь непосредственного контакта с кожей, возраст ребенка, про- должительность непосредственного контакта с кожей в течение суток. На втором этапе были рассчитаны весовые коэффициенты этих показателей. В дальнейшем для каждого признака разрабатывались оценочные шкалы градации их изменений. Детская одежда была распределена на 11 классов с учетом диапазонов изменений информативных показателей. Таким образом, в основу отечественной гигиенической классификации детской одежды заложено определение степени потенциальной опасности изделия для организма ребенка.

Применение метода интегральной оценки дало возможность установить индекс безопасности отдельных видов одежды в зависимости от площади непосредственного контакта одежды с кожей, от возрастных анатомо-физиологических особенностей организма ребенка и продолжительности непосредственного контакта одежды с кожей в течение суток.

Вывод. Предложенный подход является научным обеспечением методологии гигиенической экспертизы детской одежды. В соответствии с представленной гигиенической классификацией для каждого конкретного изделия определен индекс безопасности, устанавливающий степень риска его потенциального воздействия на здоровье детского и взрослого населения.

Ключевые слова: детская одежда, метод интегральных оценок, индекс безопасности, отечественная гигиеническая классификация.

( Платонова А.Г., Яцковська Н.Я., Антомонов М.Ю. 
цини $€$ всебічне вивчення впливу факторів середовища на здоров'я дітей і створення сприятливих умов в усіх його аспектах [5-7].

Одним 3 провідних факторів в охороні здоров'я населення, у тому числі й дитячого, $€$ забезпечення його безпечними предметами вжитку. Відомо, що одяг потрібен людині для захисту від несприятливого впливу зовнішнього середовища, забезпечує захист поверхні шкіри від механічного пошкодження та забруднення. За допомогою одягу навколо тіла створюється штучний мікроклімат під одягом, який суттєво впливає на процеси теплообміну організму та оточуючого середовища, полегшує терморегуляторну функцію шкіри, забезпечує процеси газообміну через шкірні покрови.

Особливу увагу фахівців профілактичного напрямку медицини останнім часом привертають синтетичні тканини. Нині понад 50\% різних видів одягу виготовляється із синтетичних тканин або 3 домішками синтетичних волокон [8]. Сучасні технології дозволяють створити тканини і трикотажні полотна з високотривкої хімічної сировини зі стійкими показниками, що мають широкий діапазон фізико-гігієнічних властивостей [9]. Тим не менш, синтетичні тканини мають й низку недоліків. Найнебезпечнішим за наслідками для здоров'я $€$ можлива деструкція компонентів волокон через їхню хімічну нестабільність, яка супроводжується міграцією у навколишнє середовище і простір під одягом таких компонентів синтетичних тканин, як капролактам, акрилонітрил, сполук хлору та інших речовин, здатних подразнювати шкіру та справляти резорбтивний і алергічний вплив. 3 метою попередження несприятливого впливу на здоров'я людини факторів, пов'язаних 3 виробництвом та появою на ринку України продукції, що несе потенційну небезпеку для здоров'я дітей, було введено гігієнічну оцінку продукції і товарів дитячого асортименту [10]. Поява якісно нових тканин та розширення асорти-

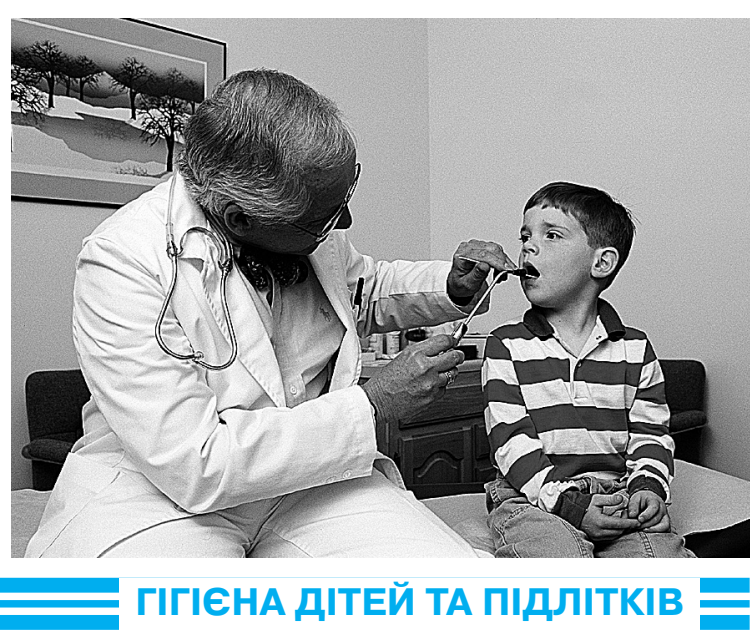

менту дитячого одягу потребують осучаснення методичних підходів і обґрунтування застосування нових показників для гігієнічної оцінки сучасних текстильних виробів для забезпечення дітей безпечною для здоров'я продукцією [11].

Метою роботи було визначити ступінь безпеки окремих видів одягу для здоров'я дітей та на цій підставі створити гігієнічну класифікацію.

Матеріали та методи. Було використано метод інтегральної оцінки, який дав змогу визначити індекс безпеки окремих видів одягу [12].

Результати та обговорення. Відповідно до технології побудови інтегральних оцінок на першому етапі визначалися інформативні показники щодо безпеки окремих видів одягу: відсоток площі безпосереднього контакту зі шкірою (S), вік дітей у роках (T), тривалість безперервного контакту зі шкірою протягом доби у годинах (t).

На другому етапі було розраховано вагові коефіцієнти цих показників. Для цього використовувався експертний метод попарного порівняння Сааті. Відповідно до нього були підготовлені матриці для заповнення експертами (табл. 1).

у таблиці $\mathbf{k}_{\mathbf{i j}}$ - коефіцієнти порівняння за 3-хбальною шкалою, при цьому $k_{\mathrm{ij}}=1 / \mathbf{k}_{\mathrm{ji}}$. Якщо і ознаки були, на думку експерта, більш значущими, ніж j, вагу $\mathbf{k}_{\mathbf{i j}}$ прирівнювали до 2 або 3 залежно від ступеня значущості. Тоді відповідні значения $\mathbf{k}_{\mathbf{j i}}$ дорівнювали 1/2 або 1/3.

Експертами виступали 9 співробітників ДУ «Інститут громадського здоров'я імені O.M. Марзєєва НАМН Ук- раїни», які мають відповідний фах і кваліфікацію.

У подальшому для кожної із заповнених таблиць розраховувалися вагові коефіцієнти $\mathbf{w}_{\mathbf{i}}$, де $\mathbf{i}$ - номер ознаки.

На наступному етапі ці вагові коефіцієнти усереднювалися 3 урахуванням рангів задіяних експертів. Ранги оцінювали 3 урахуванням вченого звання, посади і стажу роботи у відповідній галузі.

Потім коефіцієнти масштабувалися таким чином, щоб їхня сума дорівнювала «1». У результаті було встановлено значення вагових коефіцієнтів: $\mathbf{w}_{1}=\mathbf{w}_{\mathrm{S}}=0,33 ; \mathbf{w}_{2}=\mathbf{w}_{\mathrm{T}}=$ 0,$53 ; w_{3}=w_{t}=0,14$

Для кожної ознаки розроблялися оціночні шкали градацій їхніх зміни (табл. 2-4). Для цього кожному діапазону можливої зміни змінної (x) ставилося у відповідність деяке значення безрозмірного еквіваленту (d) у діапазоні від «0» до «1». Причому за «1» бралося «найбільш небезпечне» значення, за «0» - «найменш небезпечне».

Таблиця 1

Матриця попарного порівняння ознак

\begin{tabular}{|c|c|c|c|}
\hline \multirow{2}{*}{$\begin{array}{c}\text { Ознака } \\
\text { (i) }\end{array}$} & \multicolumn{3}{|c|}{ Ознака (j) } \\
\cline { 2 - 4 } & $\mathrm{S}$ & $\mathrm{T}$ & $\mathrm{t}$ \\
\hline $\mathrm{S}$ & 1 & $\mathrm{k}_{12}$ & $\mathrm{k}_{13}$ \\
\hline $\mathrm{T}$ & $\mathrm{k}_{21}$ & 1 & $\mathrm{k}_{23}$ \\
\hline $\mathrm{t}$ & $\mathrm{k}_{31}$ & $\mathrm{k}_{32}$ & 1 \\
\hline \multicolumn{4}{|c}{ Таблиця 2 }
\end{tabular}

Оціночна шкала щодо площі безпосереднього контакту зі шкірою (S, \%)

\begin{tabular}{|c|c|}
\hline $\begin{array}{c}\text { Фактичне } \\
\text { значення }(\mathrm{x})\end{array}$ & Еквівалент $\left(\mathrm{d}_{\mathrm{S}}\right)$ \\
\hline 0 & 0 \\
\hline $20 \geq \mathrm{x}>0$ & 0,2 \\
\hline $40 \geq \mathrm{x}>20$ & 0,4 \\
\hline $\mathrm{x}>40$ & 1 \\
\hline
\end{tabular}


включно;

$\square$ дітей від 11 до 14 років включно;

для дівчат і юнаків від 15 до 18 років та дорослих.

Залежно від тривалості безперервного контакту зі шкірою і частоти використання вироби за бальною системою поділяються на такі групи:

$\square$ регулярного використання (щодня від 4 годин і більше);

$\square$ епізодичного використання (1-2 рази на тиждень не більше 4 годин).

Таким чином, підсумкова формула розрахунку інтегральної оцінки (IO) ступеня небезпечності одягу для організму дитини мала такий вигляд:

IO $=0,33^{*} d_{\mathrm{S}}+0,53^{*} \mathrm{~d}_{\mathrm{T}}+0,14^{*} \mathrm{~d}_{\mathrm{t}}$.

При розрахунку інтегральної оцінки конкретних видів дитячого одягу враховувалася площа поверхні окремих анатакт зі шкірою на поверхні від 21\% до 40\% площі тіла;

мають безпосередній контакт зі шкірою на поверхні $>40 \%$ площі тіла;

$\square$ не контактують зі шкірою.

Залежно від вікових анатомо-фізіологічних особливостей організму дитини одяг поділяли на вироби для

новонароджених і дітей до 1 року включно;

$\square$ дітей від 1 до 3 років включно

$\square$ дітей від 4 до 6 років включно;

$\square$ дітей від 7 до 10 років

Таблиця

вікових особливостей організму дитини (T, рік)

\begin{tabular}{|l|c|}
\hline ёВіковий період (x) & $\begin{array}{c}\text { Еквіва- } \\
\text { лент }\left(\mathrm{d}_{\mathrm{t}}\right)\end{array}$ \\
\hline $\begin{array}{l}\text { Дівчата і юнаки від 15 } \\
\text { до 18 років та дорослі }\end{array}$ & 0,2 \\
\hline Діти від 11 до 14 років & 0,4 \\
\hline Діти від 7 до 10 років & 0,5 \\
\hline Діти від 4 до 6 років & 0,6 \\
\hline Діти від 1 до 3 років & 0,8 \\
\hline $\begin{array}{l}\text { Новонароджені та діти } \\
\text { до 1 року включно }\end{array}$ & 1 \\
\hline
\end{tabular}

Оціночна шкала щодо тривалості безперервного контакту зі шкірою протягом доби (t, години)

\begin{tabular}{|c|c|}
\hline $\begin{array}{c}\text { Фактичне } \\
\text { значення }(\mathrm{x})\end{array}$ & Еквівалент $(\mathrm{dt})$ \\
\hline $\mathrm{x} \leq 4$ & 0,5 \\
\hline $\mathrm{x}>4$ & 1 \\
\hline
\end{tabular}

томічних ділянок тіла дітей залежно від віку [13].

На заключному етапі було виконано градацію можливих діапазонів та її вербалізацію (табл. 5).

Враховуючи, що безпека дитячого одягу визначається її призначенням, складом сировини виробу, віком дитини, площею та тривалістю контакту зі шкірою, дитячий одяг слід розподілити на класи відповідно до ступеня ризику для здоров'я (табл. 6).

Запропонований підхід є науковим забезпеченням методології гігієнічної експертизи дитячого одягу. Відповідно до представленої гігієнічної класифікації для кожного конкретного виробу визначено індекс безпеки, що встановлює ступінь ризику впливу виробу на здоров'я дітей та дорослих.

Таблиця 5

Діапазон зміни величини показника інтегральної оцінки одягу залежно від площі безпосереднього контакту зі шкірою, вікової приналежності та тривалості безперервного контакту зі шкірою понад 4 годинного на добу

\begin{tabular}{|c|c|c|c|}
\hline \multirow[b]{2}{*}{$\begin{array}{c}\text { Вікова } \\
\text { група }\end{array}$} & \multirow{2}{*}{$\begin{array}{c}\text { Площа } \\
\text { безпосереднього } \\
\text { контакту зі шкі- } \\
\text { рою, \% }\end{array}$} & \multicolumn{2}{|c|}{ Величина показника інтегральної оцінки } \\
\hline & & $\begin{array}{c}\text { Тривалість безпе- } \\
\text { рервного контакту } \\
\text { зі шкірою понад } \\
4 \text { години на добу }\end{array}$ & $\begin{array}{c}\text { Тривалість безпе- } \\
\text { рервного контакту } \\
\text { зі шкірою менше } \\
4 \text { годин на добу }\end{array}$ \\
\hline \multirow{4}{*}{$\begin{array}{l}\text { Ново- } \\
\text { народ- } \\
\text { жені та } \\
\text { діти до } \\
1 \text { року }\end{array}$} & 0 & 0,67 & 0,60 \\
\hline & 20 & 0,74 & 0,67 \\
\hline & 40 & 0,80 & 0,73 \\
\hline & 100 & 1,00 & 0,93 \\
\hline \multirow{4}{*}{$\begin{array}{l}\text { Діти } \\
\text { від } 1 \\
\text { до } 3 \\
\text { років }\end{array}$} & 0 & 0,56 & 0,49 \\
\hline & 20 & 0,63 & 0,56 \\
\hline & 40 & 0,70 & 0,63 \\
\hline & 100 & 0,89 & 0,82 \\
\hline \multirow{4}{*}{$\begin{array}{l}\text { Діти } \\
\text { від } 4 \\
\text { до } 6 \\
\text { років }\end{array}$} & 0 & 0,46 & 0,39 \\
\hline & 20 & 0,52 & 0,45 \\
\hline & 40 & 0,59 & 0,52 \\
\hline & 100 & 0,79 & 0,72 \\
\hline \multirow{4}{*}{$\begin{array}{l}\text { Діти } \\
\text { від } 7 \\
\text { до } 10 \\
\text { років }\end{array}$} & 0 & 0,41 & 0,34 \\
\hline & 20 & 0,47 & 0,40 \\
\hline & 40 & 0,54 & 0,47 \\
\hline & 100 & 0,74 & 0,67 \\
\hline \multirow{4}{*}{$\begin{array}{l}\text { Діти } \\
\text { від } 11 \\
\text { до } 14 \\
\text { років }\end{array}$} & 0 & 0,35 & 0,28 \\
\hline & 20 & 0,42 & 0,35 \\
\hline & 40 & 0,48 & 0,41 \\
\hline & 100 & 0,68 & 0,61 \\
\hline \multirow{4}{*}{$\begin{array}{l}\text { Дівчата } \\
\text { і юнаки } \\
15-18 \text { р. } \\
\text { та } \\
\text { дорослі }\end{array}$} & 0 & 0,25 & 0,18 \\
\hline & 20 & 0,31 & 0,24 \\
\hline & 40 & 0,38 & 0,31 \\
\hline & 100 & 0,58 & 0,51 \\
\hline
\end{tabular}

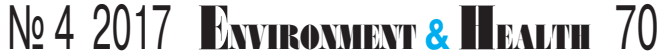


SCIENTIFIC SUBSTANTIATION OF THE CREATION OF THE DOMESTIC HYGIENIC CLASSIFICATION OF CHILDREN'S CLOTHES

Platonova A.H., Yatskovska N.Ya., Antomonov M.Yu.

SI "O.M. Marzeiev Institute of Public Health of the National Academy of Medical Sciences of Ukraine", Kyiv

Background. Provision with safe household articles, including children's one, is one of the main factors in the population health protection. The prevention of the negative impact of the unfavourable factors on human health connected with the production and appearance of the potentially unsafe products in Ukrainian market requires the revision of methodical approaches and scientific substantiation of the necessity of the use of the new indicators for hygienic assessment of modern textile goods. Objective. We established a degree of danger of separate kinds of clothes for children's health and suggested a domestic hygienic classification on its basis. Materials and methods. We used the method of integral assessment that allowed us to determine the safety index for separate kinds of clothes.

Results. According to the technology of the construction of integral assessments, the information indicators of safety of separate kinds of clothes were determined in the first stage of investigation (such as, percentage of square of direct skin contact, age of children, duration of direct contact with a skin for a day). The weight coefficients of these indicators were calculated in the second stage. Then the assessment scales for the gradation of their changes were developed for every indication. Taking into account the ranges of changes of the informative indicators, the children's clothes were divided into 11 classes. Thus, a determination of the degree of the potential danger of the goods for the child's organism is a background of the domestic classification of children's clothes. The use of integral assessment method allowed us to determine the safety index of separate kinds of clothes depending on the square of direct skin contact with clothes, age anatomical-and-physiological features of child's organism and duration of direct skin contact with clothes for a day. Conclusions. Suggested approach is a scientific provision of methodology of the hygienic expertise of children's clothes. According to the hygienic classification, the safety index was established for every product. It determines a risk degree of its potential impact on children's and adults' health.

Keywords: children's clothes, method of integral assessments, safety index, domestic hygienic classification.

\section{Гігієнічна класифікація одягу для дітей}

Таблиця 6

\begin{tabular}{|c|c|c|c|}
\hline $\begin{array}{l}\text { Шар } \\
\text { одягу }\end{array}$ & $\begin{array}{l}\text { Клас без- } \\
\text { пеки }\end{array}$ & Вид одягу & $\begin{array}{l}\text { Індекс } \\
\text { безпеки }\end{array}$ \\
\hline \multirow{7}{*}{ 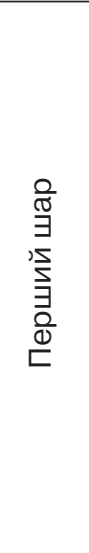 } & 1-й клас & $\begin{array}{c}\text { Одяг для новонароджених та дітей } \\
\text { до } 1 \text { року, пелюшки, постільна білизна. } \\
\text { Постільна білизна для дітей від } 1 \text { до } 3 \text { років }\end{array}$ & $1,00-0,89$ \\
\hline & 2-й клас & $\begin{array}{c}\text { Білизна, у т.ч. постільна та спортивна, } \\
\text { для дітей від } 4 \text { до } 10 \text { років }\end{array}$ & $0,79-0,74$ \\
\hline & 3-й клас & $\begin{array}{c}\text { Панчішно-шкарпеткові та купальні вироби } \\
\text { для дітей від } 1 \text { до } 6 \text { років }\end{array}$ & $0,70-0,59$ \\
\hline & 4-й клас & $\begin{array}{c}\text { Білизна, у т.ч. постільна та спортивна, } \\
\text { для дітей від } 11 \text { до } 18 \text { років }\end{array}$ & $0,68-0,58$ \\
\hline & 5-й клас & $\begin{array}{c}\text { Головні убори (літні), хустки (у т.ч. носові) } \\
\text { для дітей від } 1 \text { до } 6 \text { років } \\
\end{array}$ & $0,63-0,52$ \\
\hline & 6-й клас & $\begin{array}{c}\text { Панчішно-шкарпеткові, корсетні та } \\
\text { купальні вироби для дітей від } 7 \text { до } 14 \text { років }\end{array}$ & $0,54-0,48$ \\
\hline & 7-й клас & $\begin{array}{c}\text { Головні убори (літні), хустки (у т.ч. носові) } \\
\text { для дітей шкільного віку }\end{array}$ & $0,47-0,31$ \\
\hline \multirow{2}{*}{ 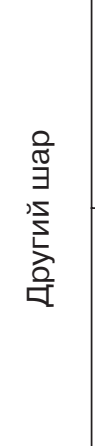 } & 8-й клас & $\begin{array}{c}\text { Вироби швейні (блузи, сорочки, штани, } \\
\text { сукні, спідниці, костюми без підкладу) та } \\
\text { вироби верхні трикотажні (джемпери, } \\
\text { пуловери, светри, рейтузи тощо), зимові } \\
\text { й осінні головні убори, рукавиці, вироби } \\
\text { спортивні для дітей від } 1 \text { до } 6 \text { років }\end{array}$ & $0,56-0,46$ \\
\hline & 9-й клас & $\begin{array}{c}\text { Вироби швейні (блузи, сорочки, штани, } \\
\text { сукні, спідниці, костюми без підкладу) та } \\
\text { вироби верхні трикотажні (джемпери, } \\
\text { пуловери, светри, рейтузи тощо), зимові } \\
\text { й осінні головні убори, рукавиці, вироби } \\
\text { спортивні для дітей молодшого та } \\
\text { середнього шкільного віку }\end{array}$ & $0,41-0,35$ \\
\hline \multirow{2}{*}{ 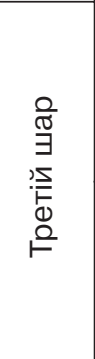 } & 10-й клас & \begin{tabular}{|c|} 
Вироби швейні костюмного та пальтового \\
асортименту (костюми, піджаки, сарафани, \\
жилети, куртки, пальта, комбінезони \\
тощо), дитячі конверти та ковдри для \\
дітей від 1 до 6 років
\end{tabular} & $0,56-0,39$ \\
\hline & 11-й клас & $\begin{array}{c}\text { Вироби швейні костюмного та пальтового } \\
\text { асортименту (костюми, піджаки, сарафани, } \\
\text { жилети, куртки, пальта, комбінезони тощо), } \\
\text { дитячі конверти та ковдри для дітей молод- } \\
\text { шого та середнього шкільного віку }\end{array}$ & $0,41-0,28$ \\
\hline
\end{tabular}

\section{Висновок}

Розроблено вітчизняну гігієнічну класифікацію дитячого одягу, в основу якої покладено ризикометричний підхід, тобто визначення ступеня безпеки виробів для організму дитини. Класифікацію розроблено з застосуванням методу інтегральної оцінки, який дав змогу визначити індекс безпеки окремих видів одягу залежно від площі безпосереднього контакту одягу зі шкірою, віковими анатомо-фізіологічними особливостями організму дитини та тривалістю безперервного контакту одягу зі шкірою протягом доби.

\section{ЛІТЕРАТУРА}

1. Полька Н.С. Сучасні наукові дослідження з гігієни дитинства і їх значення для практики. Науковий вісник Національного медичного університету імені О.О. Богомольця. 2010. № 27. C. 98-105.

2. Грузєва Т.С. Вплив екологічних чинників на формування глобального тягаря хвороб. Науковий вісник Національного медичного університету імені О.О. Богомольця. 2010. № 27. C. 167-168.

3. Сергета І.В. Навколишнє середовище та проблема збереження і зміцнення здоров'я дітей, підлітків та молоді у сучасних умовах. Режим доступу : http://eco.com.ua/ sites/eco.com.ua/files/lib1/kon 
Микробный биосенсор как инструмент биотестирования: оценка токсичности товаров народного потребления. Вестник биотехнологии и физико-химической биологии имени Ю.А. Овчинникова. 2011. Т. 7, № 2. С. 11-17.

12. Антомонов М.Ю.

Математическая обработка и анализ медико-биологических данных. К., 2006. 558 с.

13. Оказание стационарной помощи детям (Руководство по ведению наиболее распространенных болезней детского возраста) : Карманный справочник. 2-е изд.

Женева: ВО3, 2013. 412 с. REFERENCES

1. Polka N.S. Naukovyi visnyk Natsionalnoho medychnoho universytetu imeni O.O. Bohomoltsia. 2010 ; 27 : 98105 (in Ukrainian).

2. Hruzieva T.S. Naukovyi visnyk Natsionalnoho medychnoho universytetu imeni O.O. Bohomoltsia. 2010 ; 27 : 167-168 (in Ukrainian).

3. Serheta I.V. Navkolyshnie seredovyshche ta problema zberezhennia i zmitsnennia zdorovia ditei, pidlitkiv ta molodi v suchasnykh umovakh [Environment and Problem of the Preservation and

Strengthening of the Health of Children, Adolescents, and Youth under Modern

Conditions]. Available at :

http://eco.com.ua/sites/eco.co m.ua/files/lib1/konf/2vze/zb_m 10176 zb $m$ 2VZE.pdf

(in Ukrainian).

4. Melnichenko P.I. Arkhangelskiy V.I., Kozlova T.A. et al. Gigiiena s osnovami ekologii cheloveka : uchebnik [Hygiene with the Background of Human Ecology : Manual]. Moscow : GEOTAR-Media; 2010 : 752 p. Available at : http://www.studmedlib.ru/book /ISBN9785970413951.htmI (in Russian).

5. Fourth Ministerial Conference on Environment and Health, Budapest, Hungary, 23-25 June 2004. (EUR/04/5046267/6).

Available at:

http://www. euro.who.int/ data/ assets/pdf_file/0011/88580/E8 3335R.pdf

6. Fifth Ministerial Conference on Environment and Health «Protecting Children's Health in a Changing Environment», Parma, Italy, 10-12 March 2010. Declaration (EUR/55934/5.1 Rev. 2). Available at: http://www. euro.who.int/ data/ assets/pdf_file/0011/78608/E9 3618. pdf? $\bar{u} a=1$

7. Natsionalna stratehiia reformuvannia systemy okhorony zdorovia v Ukraini na period 2015-2020 roki [National Strategy of the Reforming of Health Protection System in Ukraine for the Period of 2015 2020]. Available at: http://uoz.cn.ua/strategiya.pdf (in Ukrainian).

8. Gurovich K.A. Osnovy materialovedeniia shveinogo proizvodstva [Background of Sewing Production Materials Science]. Moscow :

Akademiia ; 2013 : 208 p.

(in Russian).

9. Savostitskiy N.A.

Materialovedenie shveinogo proizvodstva [Materials Science of Sewing Production].

Moscow : Akademia ; 2004 : 181 p. (in Russian).

10. Pro zabezpechennia sanitarnoho ta epidemichnoho blahopoluchchia naselennia : Zakon Ukrainy vid 24 liutoho 1994 № 4004-XII [On the Provision of Sanitary and Epidemiological Well-Being of the Population : Law of Ukraine of February 24, 1994, № 4004XII]. Available at : http://zakon4. rada.gov.ua/laws/show/400412 (in Ukrainian)

11. Tomilova Yu.E., Chernukhin V.A. and Dekhtiarev C.Kh. Vestnik biotekhnologii I fizikochimicheskoi biologii imeni

Yu.A. Ovchinnikova. $2011 ; 7$ (2) : 11-17 (in Russian).

12. Antomonov M.Yu. Matematicheskaia obrabotka I analiz medico-biologicheskikh dannykh [Mathematical Processing and Analysis of Medico-

Biological Data]. Kiev ; 2006 : 558 p. (in Ukrainian).

13. Okazanie statsionarnoi pomoshchi detiam (Rukovodstvo po vedeniyu naibolee rasprostranennykh bolezney detskogo vozrasta) :

Karmannyy spravochnik [Provision of In-patient Care for Children (Guidelines for the Management of the Most Common Childrens' Diseases): Pocket Guide]. Geneve : WHO ; 2013 : 412 p.

Надійшла до редакції 17.08.2017 